\title{
HOW FAR IS ENVIRONMENTAL ENGINEERING FROM BIOMEDICAL ENGINEERING?
}

\author{
INTEGRACJA WIEDZY POMIĘDZY INŻYNIERIĄ ŚRODOWISKA \\ A INŻYNIERIĄ BIOMEDYCZNĄ
}

\begin{abstract}
The development of science, which has been observed in recent years, shows that engineering knowledge and activity are becoming more and more interdisciplinary. Up to the late 80-ties of the previous century, the experience and interest of engineers covered mainly hard sciences that directly followed their education. After this period, the engineering knowledge and solutions proposed in one discipline started to be applied successfully in other domains. This tendency can be seen especially in Biomedical Engineering, which development is based on achievements made in the rest of hard sciences, even if they seem to be as distant as Environmental Engineering.
\end{abstract}

Keywords: biomedical engineering, environmental engineering, transfer of knowledge, research transfer, transport phenomena

\section{Introduction}

Engineering is defined as an activity that handles the application of scientific, economic, social, and practical knowledge in order to design, build, maintain, and improve the functioning of the wide variety of constructions, machines, devices, systems, materials, and processes. In other words, the engineering practice allows using properties of matter, energy, and abstract objects for the creation of constructions, machines, and products that are being devoted to solve existing problems.

An engineer resolves problems that are necessary to be solved, but they are usually not determined unambiguously at the beginning. Therefore, scientists usually propose several solutions and they estimate them with regard to their usefulness, safety, and economy. Then, on the grounds of obtained results, they chose the solution that fulfils assumed and desired output requirements. The development of the appropriate mathematical model is usually an

\footnotetext{
${ }^{1}$ Higher Vocational State School of President Stanisław Wojciechowski in Kalisz, ul. Nowy Świat 4, 62-800 Kalisz, Poland, email: r.zarzycki@pwsz-kalisz.edu.pl

${ }^{2}$ Faculty of Process and Environmental Engineering, Lodz University of Technology, ul. Wólczańska 175, 90-924 Łódź, Poland

*Corresponding author: r.zarzycki@pwsz-kalisz.edu.pl
} 
essential work tool of engineers. The mathematical model allows analyzing and testing of potential solutions while simultaneously saving time and money.

Generally, there can be distinguished five major engineering disciplines: civil, mechanical, electrical, chemical, and bioengineering (Table 1). The process of their progression was as follows: Civil Engineering came into being based on the engineering principles used by the military. Upon human development and discoveries in mechanics and electricity, Mechanical Engineering and Electrical Engineering emerged. The above-mentioned disciplines are based on mathematics and physics. The industry's necessity for application of chemical reaction and processes in order to meet requirements of the world's growing population led to the progression of Chemical Engineering. Chemical Engineering is built upon mathematics, physic, and chemistry. Currently, the fifth 'traditional' discipline in engineering is being defined - Bioengineering. It is predicted that the next 100 years will be the century of biology, and therefore Bioengineering is based on mathematics, physic, chemistry, and a basic understanding of biology and/or living systems. Upon unlocking the secrets of very subtle mechanisms that regulate and control processes in living organisms, the aim of Bioengineering will be to apply engineering knowledge in order to get the best advantage from technological processes involving the presence of living organisms or to restore malfunctioning parts of the living system. Nowadays, we are witnesses of the creation of numerous subsets of Bioengineering: Bioprocess Engineering, Biomedical Engineering, Tissue Engineering, just to name but a few.

Table 1

Progression of 'traditional' disciplines in Engineering

\begin{tabular}{|c|c|c|c|c|}
\hline Discipline in Engineering & \multicolumn{4}{|c|}{ Sciences } \\
\hline Civil Engineering & & & & \\
\hline Mechanical Engineering & Mathematics & Physics & & \\
\hline Electrical Engineering & & & & \\
\hline Chemical Engineering & Mathematics & Physics & Chemistry & \\
\hline Bioengineering & Mathematics & Physics & Chemistry & Biology \\
\hline
\end{tabular}

Modern solutions that are being applied by scientists in order to solve current problems are based on interdisciplinary knowledge. Moreover, mathematical functions and equations used in one discipline can be easily transferred to another one. For example Chemical Engineering can benefit from solutions applied in Mechanical Engineering, and Bioengineering can profit from Chemical as well as Mechanical Engineering [1, 2].

In order to illustrate the usefulness of interdisciplinary approach to engineering domains we will discuss solutions proposed in two exemplary subdomains. The first subdomain will be a subdomain of Chemical Engineering - Environmental Engineering, and the second one will be a subdomain of Bioengineering - Biomedical Engineering. By discussing theoretical similarities between both main domains, we will try to answer the following question: can we move over the same functions and equations in Environmental Engineering to Biomedical Engineering, and contrariwise? And more generally, is it possible to share and transfer the basic knowledge applied in one engineering domain to another one? 


\section{Engineering basis of Environmental Engineering and Biomedical Engineering}

The emergence of Environmental Engineering was connected with the rise of environmental degradation caused by the humankind's activity. Environmental Engineering covers studies which are aimed at understanding and determining the influence of economic activity on the natural resources. Moreover, its goal is also to solve environmental problems that are related to the pollution and degradation of the environment.

The solutions proposed in Biomedical Engineering are based on achievements of medicine and engineering and have assisted in the struggle against malfunctioning of the human body by providing appropriate tools: biosensors, biomaterials, image processing, and artificial intelligence, just to name but a few.

There are significant analogies between Environmental Engineering and Biomedical Engineering. The aim of both above-mentioned subdomains is to solve problems with the use of knowledge, experience, and intuition. They apply principles of mathematics and physics in order to explain phenomena that occur in the natural environment and living organisms, respectively. Moreover, both of them apply chemistry to study and describe macroscopic behaviour of molecular structures and materials. From the engineering point of view, we can distinguish the following common problems that need to be considered and solved in both subdomains:

1. fluid flow and processes of momentum, heat, and mass exchange;

2. chemical and biochemical reactions;

3. processes occurring on the interphase surface: gas-liquid, solid-liquid, gas-solid (eg adsorption, desorption, liquid evaporation).

The basis of theoretical consideration of the fluid flow (both laminar and turbulent) concerning processes of momentum, heat, and mass exchange are grounded on phenomenological equations that describe mechanisms of transport in particular phenomena. These equations can be expressed with the use of the flux density in relation to the appropriate kinematic coefficient and the gradient of the considered variable: velocity for momentum exchange, temperature for heat exchange, and concentration of the considered compound for mass exchange. Below, the fundamental relationship describing these phenomena will be discussed.

Beginning with the general form of the transport mechanism (constitutive equations):

$$
\text { flux density }=- \text { kinematic coefficient } \cdot \text { gradient of variable }
$$

The following relationships can be obtained:

1. Exchange of momentum (Newton's equation):

$$
\frac{\tau}{\rho}=-v \frac{d v_{x}}{d x}
$$

where: $\tau$ - shear stress $[\mathrm{Pa}] ; \rho$ - fluid density $\left[\mathrm{kg} \cdot \mathrm{m}^{-3}\right] ; v$ - kinematic viscosity $\left[\mathrm{m}^{2} \cdot \mathrm{s}^{-1}\right]$; $v_{x}$ - fluid velocity in the direction of the $\mathrm{x}$-axis $\left[\mathrm{m}^{\cdot} \mathrm{s}^{-1}\right] ; x$ - variable $[\mathrm{m}]$.

2. Exchange of heat (Fourier's equation): 


$$
\frac{q}{c_{p} \rho}=-\alpha \frac{d T}{d x}
$$

where: $q$ - flux of heat flow $\left[\mathrm{W} \cdot \mathrm{m}^{-2}\right] ; c_{p}$ - heat capacity $\left[\mathrm{J} \cdot \mathrm{kg}^{-1} \cdot \mathrm{K}^{-1}\right] ; \alpha$ - heat diffusivity $\left[\mathrm{m}^{2} \cdot \mathrm{s}^{-1}\right] ; T$ - temperature $[\mathrm{K}]$.

3. Exchange of mass (Fick's first law):

$$
J_{A}=-D_{A B} \frac{d C_{A}}{d x}
$$

where: $J_{A}$ - flux of component $A\left[\mathrm{~kg} \cdot \mathrm{m}^{-2} \cdot \mathrm{s}^{-1}\right] ; D_{A B}$ - diffusion coefficient $\left[\mathrm{m}^{2} \cdot \mathrm{s}^{-1}\right] ; C_{A}$ concentration of component $A\left[\mathrm{~kg} \cdot \mathrm{m}^{-3}\right]$.

In the case of turbulent flow the appropriate equations will be extended by the appropriate kinematic coefficients taking into account turbulence of the flow: turbulent kinematic viscosity, turbulent heat diffusivity, and turbulent diffusion coefficient, respectively.

The above-mentioned equations describe the movement of fluid only in one dimension (in this case along the $\mathrm{x}$-axis). These considering can be transferred to three-dimensional system. Moreover, particular balances can be solved for a differential volume element (Fig. 1).

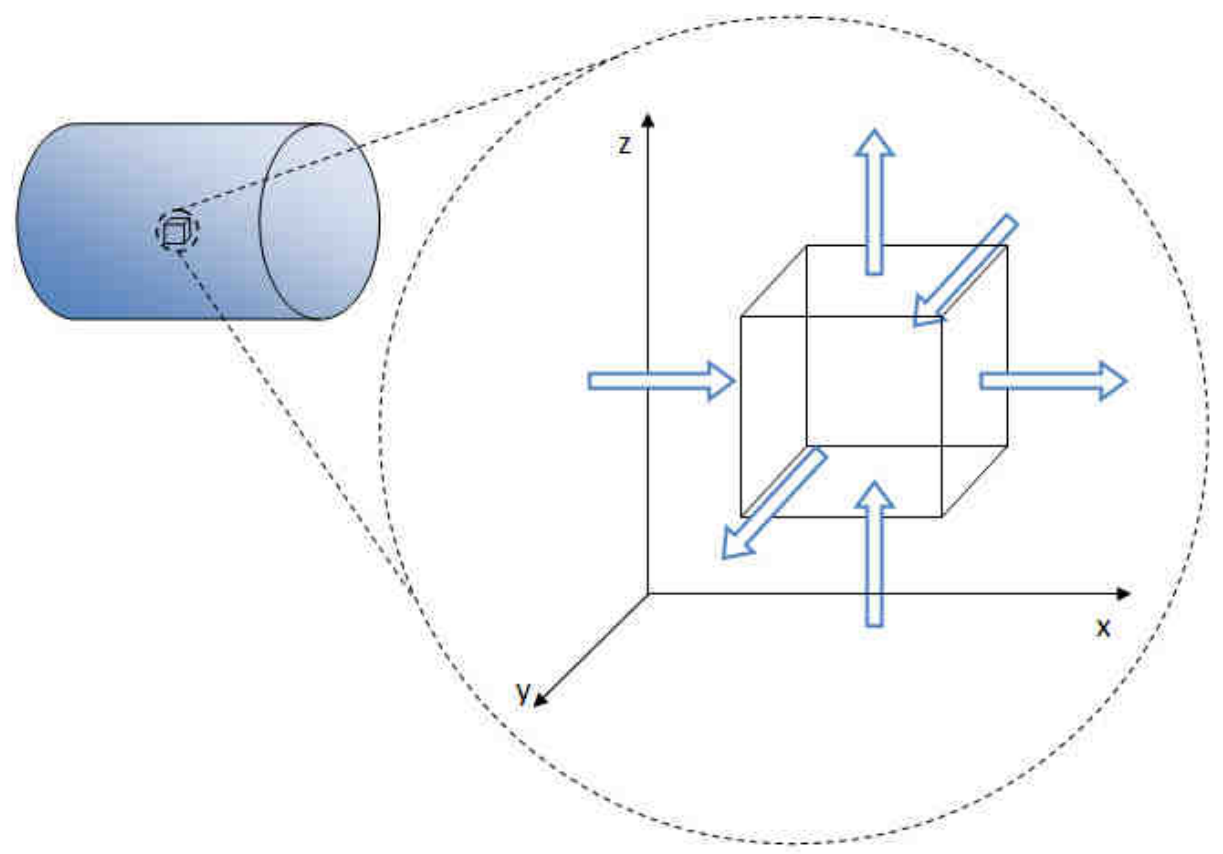

Fig. 1. Differential volume of the considered element

Differential balance equations will take the following forms, respectively:

1. Exchange of momentum - Navier-Stokes equation (along the $\mathrm{x}$-axis): 


$$
\frac{d v_{x}}{d x}+v_{x} \frac{d v_{x}}{d x}+v_{y} \frac{d v_{x}}{d y}+v_{z} \frac{d v_{x}}{d z}=X-\frac{1}{\rho} \frac{d p}{d x}+v\left(\frac{d^{2} v_{x}}{d x^{2}}+\frac{d^{2} v_{x}}{d y^{2}}+\frac{d^{2} v_{x}}{d z^{2}}\right)
$$

2. Exchange of heat (along the $\mathrm{x}$-axis):

$$
\frac{d T}{d x}+v_{x} \frac{d T}{d x}+v_{y} \frac{d T}{d y}+v_{z} \frac{d T}{d z}=\frac{\lambda}{c_{p} \rho}\left(\frac{d^{2} T}{d x^{2}}+\frac{d^{2} T}{d y^{2}}+\frac{d^{2} T}{d z^{2}}\right)
$$

3. Exchange of mass (along the $\mathrm{x}$-axis):

$$
\frac{d C_{A}}{d x}+v_{x} \frac{d C_{A}}{d x}+v_{y} \frac{d C_{A}}{d y}+v_{z} \frac{d C_{A}}{d z}+r_{A}=D_{A B}\left(\frac{d^{2} C_{A}}{d x^{2}}+\frac{d^{2} C_{A}}{d y^{2}}+\frac{d^{2} C_{A}}{d z^{2}}\right)
$$

The appropriate criterion numbers and equations describing relationships between them, which are used to calculate appropriate coefficients, will also be the same.

Further modelling of real processes occurring in both the environment and the living organism needs to take into account all chemical and biochemical reactions and phase processes that may take place in the considered system.

Some examples of the use of above-mentioned equations to solve problems in Environmental Engineering and Biomedical Engineering will be shown in the next subsection.

\section{Solution of problems in Environmental Engineering and Biomedical Engineering}

The constitutive equations of fluid dynamics can be used for describing fluid flow in both Environmental Engineering and Biomedical Engineering. The first domain elaborates on modelling of flow in the natural environment and in industrial apparatus. The examples of solutions of these problems in Environmental Engineering are widely described in books concerning them [3,4]. Biomedical engineering uses constitutive relationships in order to model flow phenomena that take place in the human body, such as the flow of blood in arteries, veins, and capillaries. Whereas the flow in the environment and industrial apparatus seem to be relatively easy to model, the one occurring in human body is more demanding. The modelling of flow in processes taking place in Environmental Engineering often concerns only the flow of substances which composition can be easily defined in place and time. Moreover, the flow takes place in stiff and defined boundaries. The difficulty of modelling of processes within the human body is caused by the fact that the composition of fluid and the structure of blood vessels are influenced by the body's local chemical and physical factors. The composition of blood changes both with time and place as it flows through vessels. Blood is a suspension of blood cells in plasma. The components of blood can interact with each other and with the wall of blood vessels. In addition, very strong turbulences in the profile of velocity in the axis of the current are observed during its flow. They are caused by the presence of shear stress. Tension is minimal in the axis of the current and grows linearly in the direction of the tube wall. This phenomenon causes the Magnus effect. Blood cells are transported in the direction of the axis of the current. The concentration of them is bigger in this region, and therefore, it disturbs the profile of velocity. Moreover, the transport of blood cells in the axis of the current causes the creation 
of the layer of pure plasma, in which the laminar flow is predominant. The structure of blood vessels also influences the flow. The mean arterial pressure is identical throughout the body. Changes in blood current through individual organs are controlled intrinsically by modifying the diameter of local arterioles supplying the capillaries. In this way organs regulate their own blood flow by varying resistance of their arterioles. In addition, in most tissues, declining levels of nutrients, particularly oxygen, are the strongest stimuli for autoregulation of the intensity of the blood current. The description of blood flow is widely described in the following books [5, 6].

In the description of the heat exchange are also used the same theoretical relationships in Environmental Engineering and Biomedical Engineering. Several cases of heat exchanges in both the natural environment and industrial apparatus are described in the book [4]. In this domain, one of the most important topics is a problem of planning for thermal isolation of a building. Figure 2 shows main mechanisms that need to be taken into account when an engineer wants to predicts the main sources of heat losses and gains.

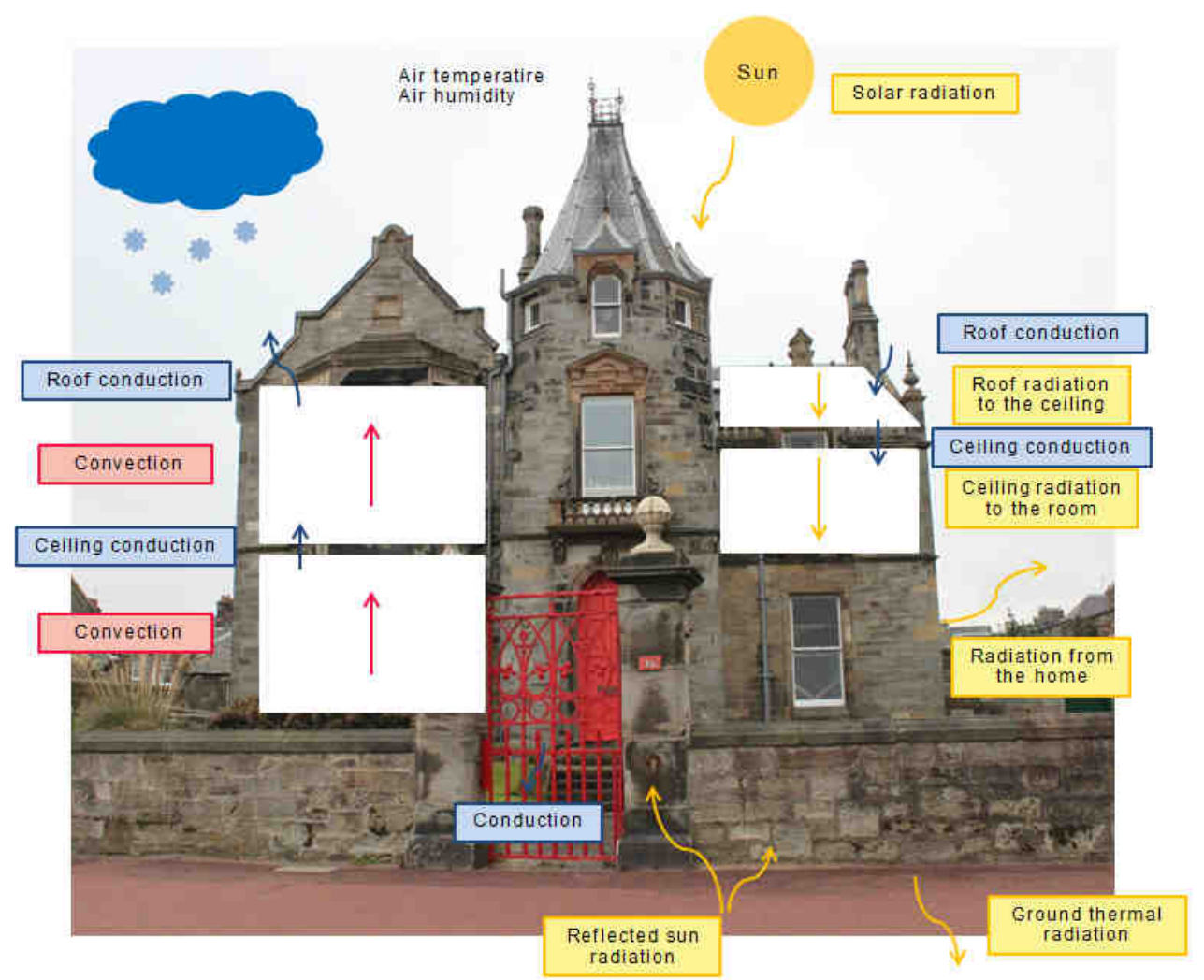

Fig. 2. Mechanisms of heat losses and gains in the building

The phenomena of heat exchange in the living organism are very interesting too. However this issue is much more complicated as a very complicated and inhomogeneous temperature filed is presented in worm-blooded organisms. Figure 3 shows model of heat 
transfer from the body to the environment. When describing the distribution of temperature in a living organism the following regions are distinguished: the core (interior) and the external layer (coating). This distinction is caused by the diversification of heat production by different organs, their irregular shapes, convective heat transport through blood vessels and different thermal isolation in different parts of the body. The temperature of the organism is constant in the core and it is approximately equal to $37^{\circ} \mathrm{C}$.

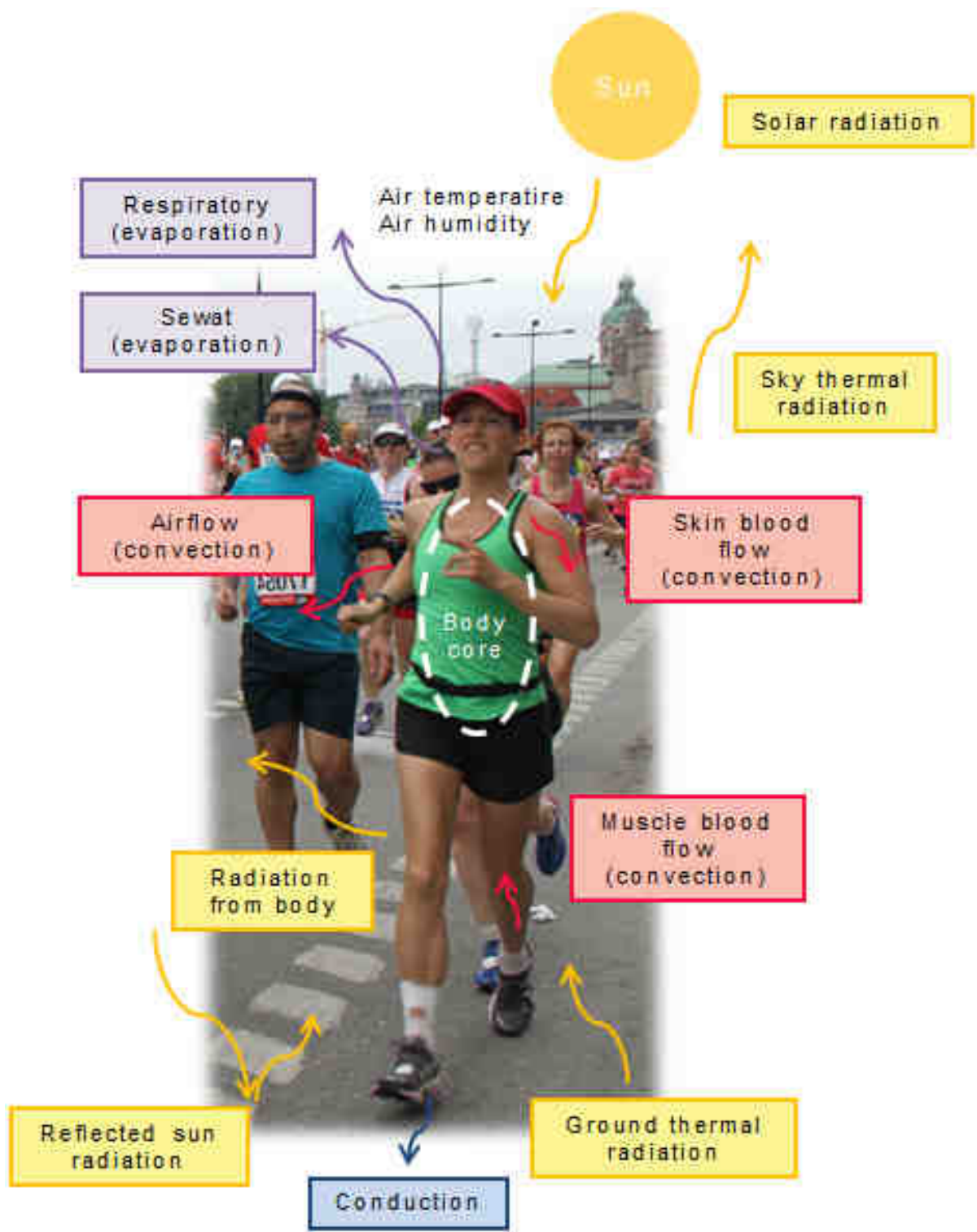

Fig. 3. Mechanisms of heat transfer from the body to the environment 
The core incorporates the following parts: the interior of the skull, the interior of the abdomen, and the interior of muscles. There are observed bigger oscillation of temperature in the external layer than in the core. However, the boundary between the core and the external layer is fluxional and it depends on external conditions, in which the organism is currently staying. The heat transport generated in the organism's core to the external layer is conducted by heat conduction and convection. In the case when the organism is surrounded by air, the heat is exchanged between the organism and the surrounding by radiation, convection, and evaporation. The theoretical bases of these processes are excellently described in the position [7].

The description of phase processes is very important in both Environmental Engineering and Biomedical Engineering. In the below section, two cases of such phenomena will be presented. The first example concerns the case occurring in Environmental Engineering. It describes the use of mass balance equation in order to model processes taking place during the sewage treatment. The mass balance was solved for the bead which is composed from chitosan granules. The bead is an adsorbent of metals (eg silver, copper) and it is in the form of spheres (Fig. 4).

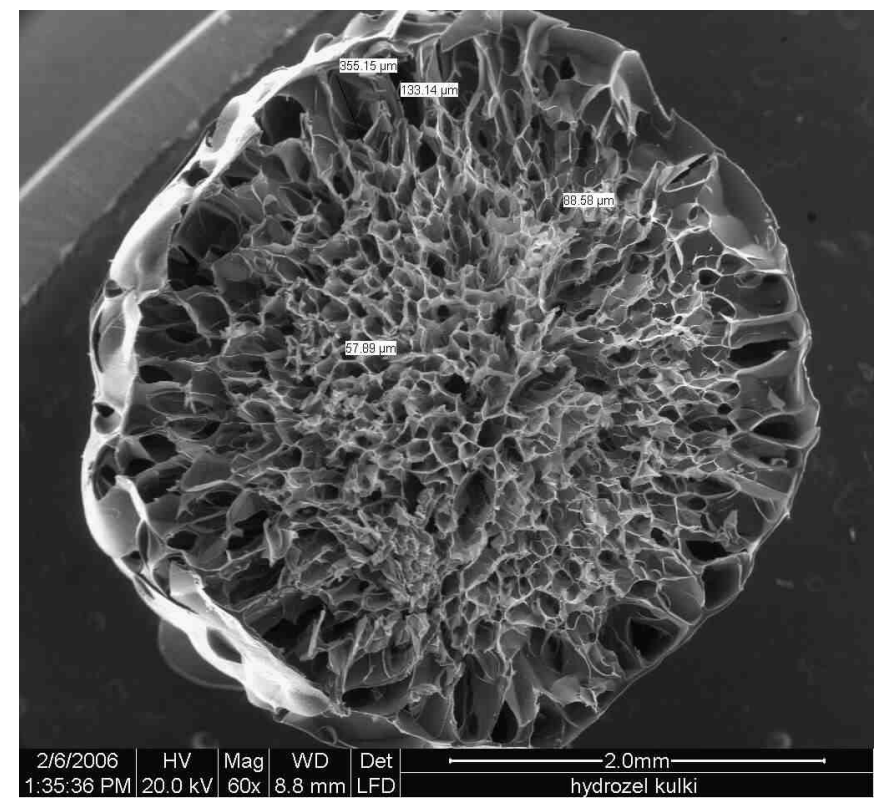

Fig. 4. The cross-section of chitosan granule

The second example concerns Biomedical Engineering and was solved for the controlled release of bioactive molecules from chitosan hydrogel. Its exact description is presented in the paper [8]. The whole system is composed of a spherical matrix. Bioactive molecules are adsorbed on its surface. This case is opposite to the case presented above. The active agent is being desorbed form the solid body.

The mass balance of the active agent for both cases can be described by the following equation: 


$$
\text { accumulation }=\text { inflow }- \text { outflow }+ \text { reaction }
$$

The appropriate formulation of the model describing the processes of adsorption as well as the process of desorption involves the formulation of the appropriate balance equations for both the liquid phase and solid phase (chitosan). The mass balance of active agent for liquid phase in the case of the process of adsorption will be composed of three parts: (1) diffusion flow, (2) part describing chemical reaction, and (3) accumulation. The mass balance of active agent for solid phase will be determined by the following parts: (1) the reaction taking part on the surface and (2) mass accumulation. The whole system is presented in Figure 5.

Equation (8) takes the following form:

$$
\text { accumulation }=\text { inflow }- \text { outflow }+ \text { adsorption }
$$

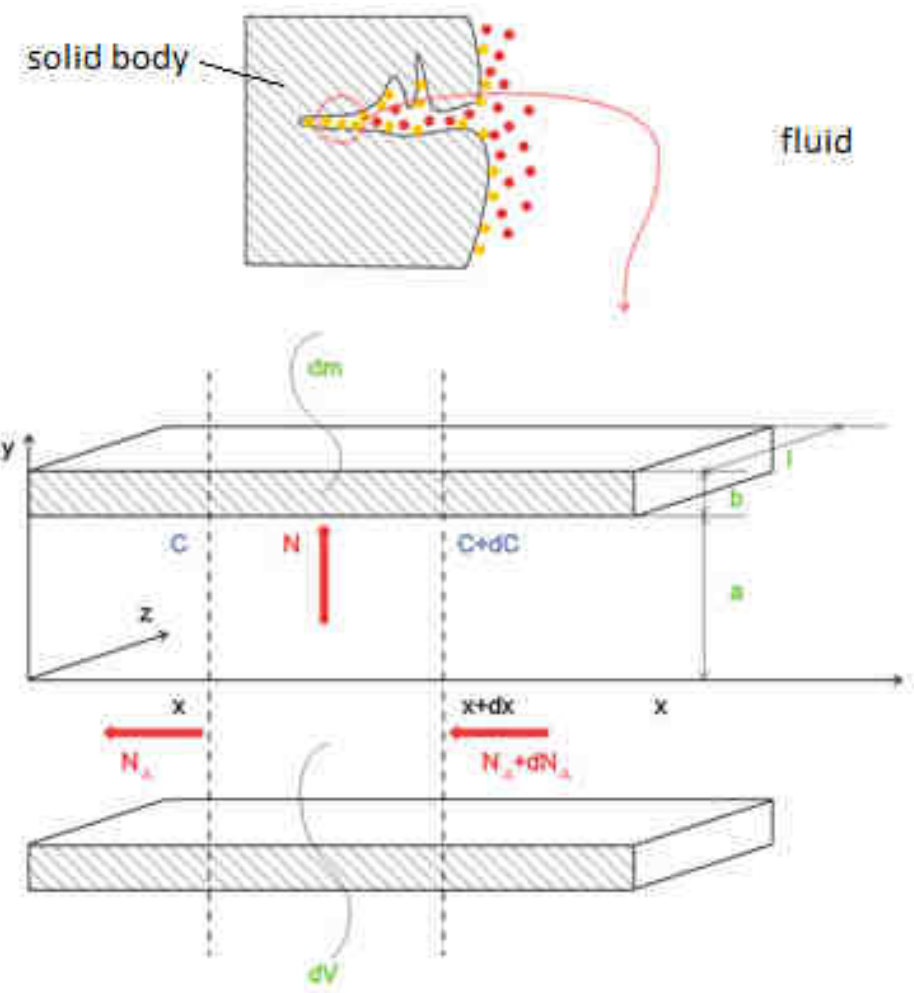

Fig. 5. Graphical representation of the process of adsorption

Assuming that the system is homogeneous and the process of diffusion is much slower than the process of surface adsorption, what leads to the assumption that the solid body is in equilibrium with liquid (in time and in space), the appropriate parts of the equation can be described by the following equations: 
- accumulation:

$$
A=d V \cdot \varepsilon \cdot \frac{d C_{A}}{d t}
$$

- inflow:

$$
D=\left(N_{A}+d N_{A}\right) \cdot \varepsilon \cdot \frac{d V}{d r}
$$

- outflow:

$$
O=N_{A} \cdot \varepsilon \cdot \frac{d V}{d r}
$$

- adsorption:

$$
A d s=N_{A}^{a d s} \cdot \rho \cdot a \cdot(1-\varepsilon) \cdot d V
$$

where: $\rho$ - polymer density $\left[\mathrm{kg} \cdot \mathrm{m}^{-3}\right], a$ - specific surface related to mass unit of the solid body $\left[\mathrm{m}^{2} \cdot \mathrm{kg}^{-1}\right], \varepsilon$ - matrix porosity $[-]$.

The adsorption kinetics can be described by the following equation:

$$
N_{A}^{a d s}=k_{L}\left(C_{A}^{*}-C_{A}\right)
$$

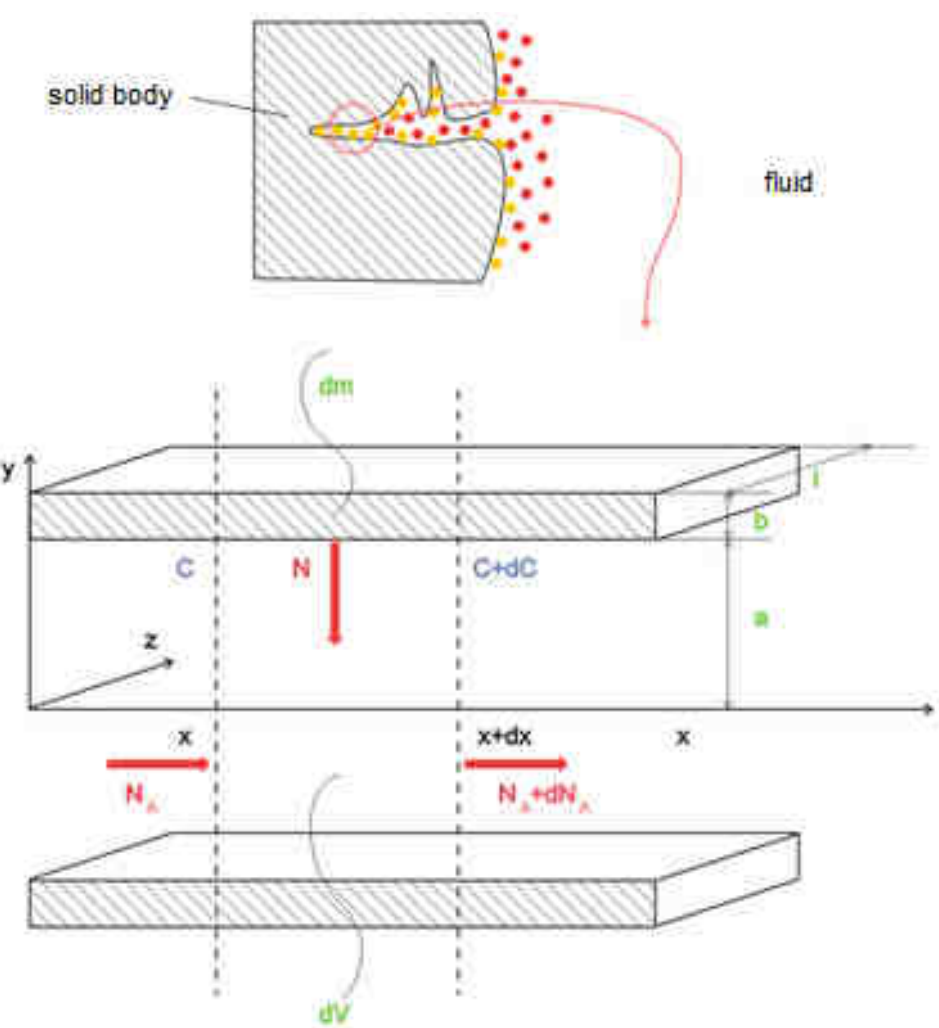

Fig. 6. Graphical representation of the process of desorption 
In the second case, the process of desorption presented in drug controlled release, the mass balance of active agent for liquid phase will be also composed of three parts: diffusion flow, the part describing chemical reaction, and accumulation. The mass balance of active agent for solid phase will be determined by the following parts: the reaction taking part on the surface and mass depletion. The whole system is presented in Figure 6.

In this case, Equation (8) takes the following form:

$$
\text { accumulation }=\text { inflow }- \text { outflow }+ \text { desorption }
$$

Assuming the similar assumption like in the case of adsorption: the system is homogeneous and the process of diffusion is much slower than the process of surface adsorption, what leads to the assumption that the solid body is in equilibrium with liquid (in time and in space), the appropriate parts of the equation can be described by the following equations:

- accumulation:

$$
A=d V \cdot \varepsilon \cdot \frac{d C_{A}}{d t}
$$

- inflow:

$$
D=N_{A} \cdot \varepsilon \cdot \frac{d V}{d r}
$$

- outflow:

$$
O=\left(N_{A}+d N_{A}\right) \cdot \varepsilon \cdot \frac{d V}{d r}
$$

- desorption:

$$
\text { Des }=N_{A}^{d e s} \cdot \rho \cdot a \cdot(1-\varepsilon) \cdot d V
$$

The desorption kinetics can be described by the following equation:

$$
N_{A}^{\text {des }}=k_{L}\left(C_{A}^{*}-C_{A}\right)
$$

where $C_{A}^{*}$ - concentration of active component $A$ in the liquid near the surface being in adsorption equilibrium with solid $\left[\mathrm{kg} \mathrm{A} \cdot \mathrm{m}^{-3}\right]$.

The equilibrium equations of adsorption as well as desorption can be written in the following form:

$$
q=\operatorname{lang}\left(C_{A}\right)
$$

The boundary and initial conditions will also be similar in both cases:

$$
\begin{array}{lc}
\text { for } t=0 & C_{A}^{*}=C_{A 0}^{*} \\
\text { for } t=0 & q=q_{0}^{*} \\
\text { for } r=0 & \frac{d C_{A}}{d t}=0
\end{array}
$$




\title{
Conclusions
}

The examples presented in this article show that the theoretical basis of the description of processes and problems that are present in Environmental Engineering and Biomedical Engineering are the same. All processes of the exchange of momentum, heat and mass can be described by the same relationship: constitutive equations and balance equations. Therefore, the solutions of these problems will be similar. However, processes taking place in the living organisms are much more complicated than in the environment and industrial apparatus. Modelling of such processes involves taking into account chemical and biochemical interactions between constituents of the living organism. Nevertheless, the knowledge form Environmental Engineering can be fully applied in Biomedical Engineering. Scientists from the both domains can share and exchange their experience and solve problems with the similar theoretical basis, but concerning different objects.

\section{References}

[1] Enderle J, Blanchard S, Bronzino J, Introduction to Biomedical Engineering. Third Edition. Oxford: Elsevier; 2011.

[2] Bronzino JD, Peterson DR. The Biomedical Engineering Handbook. Third Edition: Biomedical Engineering Fundamentals. Florida: CRC Press; 2006.

[3] Zarzycki R. Wymiana ciepła i ruch masy w inżynierii środowiska (Heat and Mass Transfer in Environmental Engineering).Warszawa: WNT; 2005.

[4] Davis M, Cornwell D. Introduction to Environmental Engineering. New York: McGraw-Hill Companies, Incorporated; 2008.

[5] Davidovits P. Physics in Biology and Medicine. California: Academic Press; 2007.

[6] Tuszynski JA, Dixon JM. Biomedical Applications for Introductory Physics. New York: Wiley; 2001.

[7] Boron WF, Boulpaep EL. Medical Physiology. Philadelphia: Elsevier; 2011.

[8] Zarzycki R, Rogacki G, Modrzejewska Z, Nawrotek K. Modeling of drug (albumin) release from thermosensitive chitosan hydrogels. Industrial Eng Chem Res. 2011;50:2866-2872. DOI: 10.1021/ie1023723.

\section{INTEGRACJA WIEDZY POMIĘDZY INŻYNIERIĄ ŚRODOWISKA A INŻYNIERIĄ BIOMEDYCZNĄ}

\author{
${ }^{1}$ Państwowa Wyższa Szkoła Zawodowa im. Prezydenta Stanisława Wojciechowskiego w Kaliszu \\ ${ }^{2}$ Wydział Inżynierii Procesowej i Ochrony Środowiska, Politechnika Łódzka
}

\begin{abstract}
Abstrakt: Rozwój nauki, który obserwuje się w ostatnich latach, wymaga czerpania i integracji wiedzy z różnych jej dziedzin. Do końca lat 80. ubiegłego wieku zainteresowania i praca inżyniera były ściśle związane ze zdobytą przez niego wiedzą i obejmowały głównie nauki ścisłe. Po tym okresie wiedza techniczna oraz rozwiązania zaproponowane w jednej dziedzinie nauki zaczęły być z powodzeniem stosowane w innych. Tendencję tę widać szczególnie w Inżynierii Biomedycznej, której rozwój opiera się na osiągnięciach dokonanych w pozostałych naukach ścisłych, nawet, jeśli wydają się one być tak odległe, jak Inżynierii Środowiska.
\end{abstract}

Słowa kluczowe: inżynieria biomedyczna, inżynieria środowiska, transfer wiedzy, transfer badań, zjawiska transportu pędu, ciepła i masy 